Jurnal Sistim Informasi dan Teknologi
https://jsisfotek.org/index .php $\begin{array}{llll}\text { Nol. } 3 & \text { No. } 4 & \text { Hal: } 239-244 & \text { e-ISSN: } 2686-3154\end{array}$

\title{
Sistem Pakar dalam Menganalisis Alergi Kulit Manusia dengan Metode Certainty Factor
}

\author{
Hafid Dwi Adha ${ }^{1 凶}$ Sumijan $^{2}$, Gunadi Widi Nurcahyo ${ }^{3}$ \\ ${ }^{1}$ Independent Researcher \\ ${ }^{2,3}$ Universitas Putra Indonesia (YPTK) Padang \\ adhahafiddwi .xrpl@gmai1.com
}

\begin{abstract}
The skin is human's outer sense, which servers as protection from bacteria, viruses, and solar flares, and as a sense. Skin may suffer from a variety of factors, one of which is allergies. Human skin allergies result from a pressurized immune system that humans normally react to certain substances, such as food, animal hair, or medicine. In addition to the three factors, a current of society giveslittle attention to skin allergies and lack of care or awareness is a trigger factor. Thus, the aim of this research is to analyze human skin allergies using the Certainty Factor method. By conducting interviews and observations on Rahmatan Lil 'Alamin Clinic, Padang City, found 10 skin allergic kinds, 27 skin allergic symptoms, and 50 patients data. Those data are treated using the Certainty Factor method with stages to decisive symptom and allergic code, set the rule, set the weight, and calculate Certainty Factor score. In this research, it obtained test results at a percentage of a large 92\% and the most allergic diagnosed is allergic dermatitis. By the test results inferable that expert system designed can be used to determine the diagnosis of human skin allergies.
\end{abstract}

Keywords: Skin Allergic, Expert System, Certainty Factor, Analyze, Skin Health.

\begin{abstract}
Abstrak
Kulit adalah indera paling luar yang dimiliki manusia, yang berfungsi sebagai pelindung dari bakteri, virus, dan sinar matahari, serta sebagai indera peraba. Kulit dapat mengalami gangguan atau penyakit yang disebabkan oleh berbagai faktor, salah satunya alergi. Alergi kulit manusia terjadi karena sistem kekebalan tubuh yang dimiliki oleh manusia bereaksi secara tidak biasanya terhadap zat tertentu, seperti makanan, bulu binatang, atau obat-obatan. Selain tiga faktor tersebut, faktor dari masyarakat yang saat ini kurang memerhatikan alergi kulit yang diderita dan kurangnya perawatan atau kesadaran juga menjadi faktor pemicu. Oleh karena itu, penelitian ini bertujuan untuk menganalisis alergi kulit manusia dengan metode Certainty Factor. Dengan melakukan wawancara dan observasi pada Klinik Rahmatan Lil 'Alamin Kota Padang, ditemukan sebanyak 10 jenis alergi kulit, 27 gejala alergi kulit, dan 50 data pasien. Data tersebut diolah dengan menggunakan metode Certainty Factor dengan tahapan menentukan kode gejala dan alergi, membentuk rule, menentukan bobot, dan menghitung nilai Certainty Factor. Pada penelitian ini diperoleh hasil pengujian dengan tingkat persentase sebesar 92\% dengan alergi yang paling banyak diderita yaitu dermatitis alergi. Dengan hasil pengujian tersebut dapat disimpulkan bahwa Sistem Pakar yang dirancang dapat digunakan untuk menentukan diagnosa alergi kulit manusia.
\end{abstract}

Kata kunci: Alergi Kulit, Sistem Pakar, Certainty Factor, Analisis, Kesehatan Kulit.

(C) 2021 JSisfotek

\section{Pendahuluan}

Kulit merupakan indera yang dimiliki oleh manusia yang memiliki berbagai macam fungsi, di antara fungsi kulit yaitu sebagai pelindung tubuh dari bakteri, virus, dan sinar matahari, sebagai indera peraba, dan sebagai indera yang dapat merasakan suhu. Kulit merupakan indera terluar pada tubuh [1]. Kulit adalah organ yang paling besar yang dimiliki oleh manusia, yang menjadi indera pertahanan pertama tubuh dari serangan luar, seperti bakteri dan virus [2]. Oleh karena itu, kulit lebih rentan mengalami gangguan atau penyakit. Gangguan atau penyakit dapat disebabkan oleh berbagai faktor, salah satunya alergi. Alergi pada kulit manusia terjadi karena sistem kekebalan tubuh yang dimiliki oleh memperoleh nilai kepercayaan dari hasil diagnosa manusia bereaksi secara tidak biasanya terhadap zat dengan nilai tingkat akurasi 94,6\% [6]. Penerapan tertentu, seperti makanan, bulu binatang, atau obat- metode Certainty Factor pada pengidentifikasian jenis obatan.
Sistem pakar adalah sebuah perangkat lunak komputer yang dapat menerjemahkan pemikiran dari para pakar dengan maksud agar dapat memecahkan masalah serta membantu menemukan solusi permasalahan dalam proses pengambilan suatu keputusan [3]. Metode Certainty Factor diperkenalkan oleh Shortliffe Buchanan dalam pembangunan Sistem Pakar MYCIN untuk menunjukkan besarnya kepercayaan [4]. Metode Certainty Factor digunakan untuk menghadapi masalah yang mana jawabannya tersebut ada unsur ketidakpastian [5].

Penelitian sebelumnya melakukan diagnosa penyakit tanaman tebu dengan metode Certainty Factor yang metode Certainty Factor pada pengidentifikasian jenis
kulit wajah dengan jumlah 40 responden wanita, 
menghasilkan $100 \%$ responden tidak memahami jenis permasalahan tingkat manusia oleh para pakar [14]. kulit wajah, 76\% mengatakan membutuhkan pakar, dan Berbagai bidang pada saat ini menggunakan Sistem 95\% membutuhkan aplikasi Sistem Pakar [7]. Pakar untuk menyelesaikan masalah-masalah yang Penelitian untuk mengidentifikasi hama kelapa sawit terjadi pada masyarakat, seperti bidang medis, teknik, dengan didapatkannya 7 jenis hama yang menyerang pertanian, dan lain lain [15].

kelapa sawit, dan serangan hama terbesar adalah hama rayap jenis Coptotermes Curvignathus sebesar $88,8 \%$ pada tanaman kelapa sawit [8].

Penelitian pernah dilakukan dengan menggunakan metode Certainty Factor untuk mengidentifikasi cacat jantung pada manusia, dengan menghasilkan nilai kepastiannya yaitu untuk jantung normal 0,95 dan dengan tingkat akurasi $95 \%$, sedangkan untuk jantung tidak normal 0.99 dengan tingkat akurasi 99\% [9]. Penerapan metode Certainty Factor juga digunakan pada penelitian untuk mengevaluasi pemetaan tanah mengenai pencegahan dan mitigasi bahaya longsor dengan 3 metode, yakni Information Value (IV) dengan hasil akurasi 86,24\%, Wieghts-of-Evidence (WofE) dengan hasil akurasi 86,34\% dan Certainty Factor (CF) dengan hasil akurasi 87,44\% [10].

Penelitian mengenai sistem pakar dengan metode Certainty Factor juga dilakukan untuk meramalkan kekeringan yang akan terjadi, dengan nilai tingkat akurasinya sebesar 94\% [11]. Pada penelitian yang dilakukan untuk diagnosa aphasia dengan metode Certainty Factor menghasilkan bahwa penelitian berjalan dengan baik hanya dengan memasukkan beberapa atribut atau domain saja [12] Metode Certainty Factor juga diterapkan untuk menangani penyakit insomnia dengan menghasilkan tingkat akurasi sebesar 93.33\% [13].

Alergi kulit pada saat ini banyak dialami oleh manusia, 2.3. Metode Certainty Factor

Metode Certainty Factor adalah metode yang biasa dipakai ketika menemukan suatu masalah yang mana jawabannya belum pasti, karena ketidakpastian tersebut menjadikan sebuah kemungkinan yang akan menghasilkan sebuah kesimpulan "mungkin" atau "tidak mungkin" [16]. Hal yang juga diperhatikan dalam metode ini yaitu pemberian nilai weight atau bobotnya terhadap gejala-gejala yang ditimbulkan yang nantinya akan berpengaruh terhadap hasil kesimpulan yang diperoleh [17]. Metode Certainty Factor dilakukan untuk melakukan pengolahan data dengan ketentuan bobot yang sesuai pada Tabel 1 yang diberikan oleh pakar.

Tabel 1. Tabel Nilai Metode Certainty Factor (CF)

\begin{tabular}{llc}
\hline No & Uncertainty Term & Nilai CF \\
\hline 1 & Tidak & 0,0 \\
2 & Tidak Tahu & 0.2 \\
3 & Sedikit Yakin & 0.4 \\
4 & Cukup Yakin & 0.6 \\
5 & Yakin & 0.8 \\
6 & Sangat Yakin & 1.0 \\
\hline
\end{tabular}

Metode Certainty Factor memiliki rumus dalam pencarian nilainya yang dibentuk pada Persamaan (1) mulai dari anak-anak hingga orang dewasa. Kebanyakan pada saat ini, masyarakat kurang memerhatikan alergi kulit yang diderita. Alergi kulit juga dapat disebabkan oleh perubahan suhu secara drastis yang dirasakan oleh tubuh, nantinya kulit akan menimbulkan merah-merah memar atau bercak. Selain yang telah diketahui secara pasti, sedangkan HD[M,n] itu, perilaku masyarakat yang mengonsumsi makanan adalah nilai Certainty Factor yang dipengaruhi oleh atau obat-obatan yang mungkin saja juga merupakan evidence $n$, dan $n$ adalah fakta, sedangkan $M$ adalah salah satu penyebab dari alergi yang dialami. Faktor hipotesis. Jika ada kaidah yang mempunyai hasil akhir lainnya, bisa dikarenakan kurangnya perawatan kulit yang sama, maka rumus HD yang diaplikasikan adalah yang dilakukan oleh masyarakat itu sendiri.

\section{Metodologi Penelitian}

\subsection{Subjek Penelitian}

Pada penelitian ini terdapat subjek berupa analisa alergi kulit manusia dengan menggunakan metode Certainty Factor untuk diterapkan pada Sistem Pakar. Topik permasalahan pada penelitian ini adalah karena kurangnya perhatian masyarakat mengenai gejala alergi kulit yang ada.

\subsection{Sistem Pakar}

Sistem pakar juga disebut sebagai salah satu cabang dari AI yang dikhususkan untuk menyelesaikan pada Persamaan (2)

$$
H D_{\text {combine }}=H D_{\text {old }}+H D_{\text {gejala }} \mathrm{X}\left(1-H D_{\text {old }}\right)
$$

Di mana $\mathrm{HD}_{\text {combine }}$ merupakan nilai Certainty Factor gabungan, $\mathrm{HD}_{\text {old }}$ merupakan nilai Certainty Factor yang pertama digunakan, dan $\mathrm{HD}_{\text {gejala }}$ merupakan nilai Certainty Factor yang kedua digunakan.

\subsection{Metode Pengumpulan Data}

Metode pengumpulan data yang digunakan adalah dengan metode studi pustaka (mencari referensi yang berkaitan dengan penelitian) dan wawancara atau observasi langsung dengan pakar pada tempat penelitian. 


\subsection{Kerangka Kerja}

Kerangka kerja merupakan suatu bagian penting dalam penelitian yang berguna sebagai pedoman dalam tahaptahap dalam melakukan setiap kegiatan pada penelitian. Kerangka kerja yang diterapkan pada penelitian ini dapat dilihat pada Gambar 1.

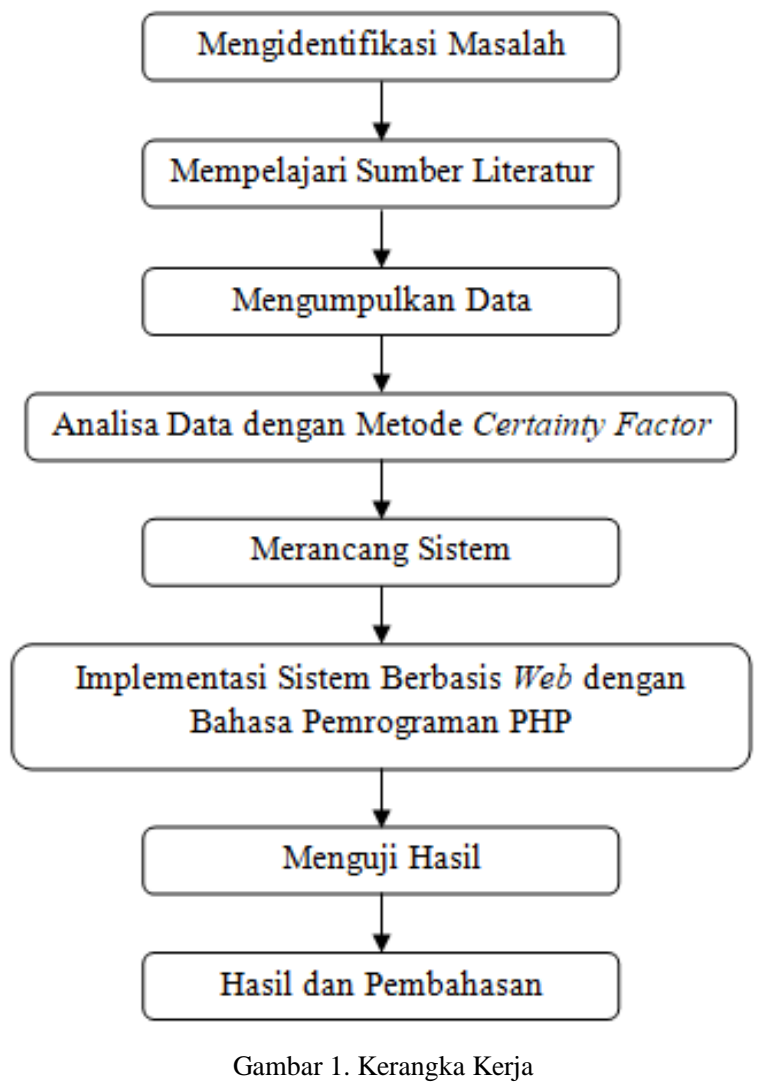

Kerangka kerja penelitian dibangung dengan tujuan agar penelitian dapat berjalan dengan tepat dan efektif, demi mencapai hasil penelitian yang baik.

\section{Hasil dan Pembahasan}

\subsection{Analisis Data}

Pada penelitian ini data yang dibutuhkan adalah data mengenai alergi kulit pada manusia, gejala alergi kulit pada manusia, solusi penanganan diagnosa, dan data pasien yang diolah pada Sistem Pakar yang dibangun. Data pada penelitian ini diperoleh berdasarkan wawancara dan observasi langsung ke tempat penelitian terhadap pakar. Data disajikan pada Tabel 2.

Tabel 2. Tabel Alergi Kulit Manusia

\begin{tabular}{rcl}
\hline No & Kode & Alergi \\
\hline 1 & A01 & Dermatitis Alergi \\
2 & A02 & Dermatitis Iritan \\
3 & A03 & Erisipelas \\
4 & A04 & Veruca \\
5 & A05 & Urtikaria \\
6 & A06 & Hidradenitis \\
7 & A07 & Miliaria \\
8 & A08 & Tinea Corporis \\
9 & A09 & Tinea Pedis \\
10 & A10 & Tinea Cruris \\
\hline
\end{tabular}

Diperoleh sebanyak 10 jenis alergi kulit yang umum terjadi pada masyarakat. Setiap alergi kulit tersebut diberi kode yang dimulai dari A01 hingga A10, yang dapat dilihat pada Tabel 2. Adapun data gejala pada alergi kulit manusia yang biasa dirasakan oleh masyarakat dapat dilihat pada Tabel 3.

Tabel 3. Tabel Gejala Alergi Kulit Manusia

\begin{tabular}{rrl}
\hline No & Kode & \multicolumn{1}{c}{ Gejala } \\
\hline 1 & G01 & Bersin dan batuk \\
2 & G02 & Sesak nafas \\
3 & G03 & Hidung berair \\
4 & G04 & Mata merah \\
5 & G05 & Mata berair \\
6 & G06 & Mata gatal \\
7 & G07 & Kulit kering \\
8 & G08 & Kulit perih \\
9 & G09 & Kulit bersisik \\
10 & G10 & Kulit melepuh \\
11 & G11 & Kulit pecah-pecah \\
12 & G12 & Ruam kemerahan \\
13 & G13 & Sulit bicara atau menelan \\
14 & G14 & Tekanan darah turun drastis \\
15 & G15 & Denyut nadi cepat tapi lemah \\
16 & G16 & Gatal pada kulit yang mengalami ruam \\
17 & G17 & Bengkak pada bagian tubuh yang terpapar dengan alergen \\
18 & G18 & Pingsan atau tidak sadarkan diri \\
19 & G19 & Bengkak pada lidah maupun bibir \\
20 & G20 & Nyeri pada kulit yang mengalami ruam \\
21 & G21 & Muncul benjolan seperti kutil \\
22 & G22 & Muncul bentol tidak berisi \\
23 & G23 & Inveksi kulit oleh kuman \\
24 & G24 & Bisul pada ketiak \\
25 & G25 & Kulit bersisik pada area selangkangan \\
26 & G26 & Kulit bersisik pada area kaki \\
27 & G27 & Kulit bersisik pada area badan \\
\hline & &
\end{tabular}

Pada penelitian ini diperoleh gejala sebanyak 27 gejala yang biasa dirasakan oleh masyarakat terhadap alergi kulit. Setiap gejala diberikan kode yang dimulai dari G01 hingga G27. Penelitian ini memiliki rule atau aturan yang berguna sebagai langkah pencarian yang akan dilakukan untuk mencari nilai Certainty Factor yang dapat dilihat pada Tabel 4.

Tabel 4. Tabel Gejala Alergi Kulit Manusia

\begin{tabular}{|c|c|c|}
\hline No & Rule & $\mathrm{CF}$ \\
\hline 1 & $I F$ [G17] $A N D$ [G16] AND [G01] THEN A01 & 0.8 \\
\hline 2 & $I F[\mathrm{G} 17]$ AND [G16] AND [G01] AND [G03] THEN A01 & 0.8 \\
\hline 3 & $I F[\mathrm{G} 17] A N D$ [G16] AND [G06] AND [G05] THEN A01 & 0.8 \\
\hline 4 & $I F[\mathrm{G} 16]$ AND [G01] AND [G02] THEN A01 & 0.6 \\
\hline 5 & IF [G17] AND [G04] AND [G05] THEN A01 & 0.6 \\
\hline 6 & $I F[\mathrm{G} 16]$ AND [G01] AND [G03] AND [G05] THEN A01 & 0.8 \\
\hline 7 & IF [G16] AND [G07] AND [G11] THEN A02 & 0.6 \\
\hline 8 & IF [G16] AND [G08] AND [G10] THEN A02 & 0.6 \\
\hline 9 & IF [G16] AND [G09] AND [G07] THEN A02 & 0.8 \\
\hline 10 & $I F[\mathrm{G} 23] A N D$ [G12] AND [G16] AND [G20] THEN A03 & 1.0 \\
\hline 11 & IF [G21] AND [G16] AND [G20] THEN A04 & 0.6 \\
\hline 12 & IF [G16] AND [G17] AND [G12] THEN A05 & 1.0 \\
\hline 13 & IF [G16] AND [G17] AND [G19] AND [G13] THEN A05 & 0.6 \\
\hline 14 & $\begin{array}{l}I F[\mathrm{G} 16] A N D[\mathrm{G} 17] A N D[\mathrm{G} 12] A N D[\mathrm{G} 02] A N D \\
{[\mathrm{G} 14] \text { THEN A05 }}\end{array}$ & 0.8 \\
\hline 15 & IF [G16] AND [G12] AND [G15] AND [G18] THEN A05 & 0.6 \\
\hline 16 & $I F[\mathrm{G} 24] A N D[\mathrm{G} 16]$ AND [G20] THEN A06 & 0.8 \\
\hline 17 & IF [G22] AND [G12] AND [G16] THEN A07 & 1.0 \\
\hline 18 & IF [G22] AND [G12] AND [G20] THEN A07 & 0.8 \\
\hline 19 & IF [G26] AND [G16] THEN A08 & 1.0 \\
\hline & IF [G27] AND [G16] THEN A09 & 1.0 \\
\hline & IF [G25] AND [G16] THEN A010 & 1.0 \\
\hline
\end{tabular}


Setelah dibentuknya rule dan pemberian nilai pada tiap- akan diolah pada Sistem Pakar yang dibangun. tiap rule oleh pakar, maka dilakukan pencarian nilai Persentase akurasi yang dihasilkan oleh sistem diolah Certainty Factor dengan menggunakan Rumus (1) atau dengan menggunakan rumus

(2) pada sample data pasien pada Tabel 5.

Tabel 5. Tabel Sample Data

\begin{tabular}{|c|c|c|c|c|}
\hline No & Pasien & Kode Gejala & Tingkat Keyakinan & $\mathrm{CF}$ \\
\hline \multirow{3}{*}{1} & \multirow{3}{*}{ Pasien 1} & G16 & Yakin & 0.8 \\
\hline & & G07 & Yakin & 0.8 \\
\hline & & G09 & Yakin & 0.8 \\
\hline \multirow{3}{*}{2} & \multirow{3}{*}{ Pasien 2} & G07 & Yakin & 0.8 \\
\hline & & G11 & Kurang Yakin & 0.4 \\
\hline & & G16 & Yakin & 0.8 \\
\hline
\end{tabular}

Proses perhitungan pada Pasien-1, di mana tingkat keyakinan menggunakan perhitungan Certainty Factor merujuk pada Rumus (2) adalah:

$$
\begin{aligned}
\text { HD1 } & (\mathrm{A} 02, \mathrm{G} 16 \cap \mathrm{G} 08 \cap \mathrm{G} 08) \\
& =\operatorname{Min}[0,8 ; 0,8 ; 0.8] \times 0,8 \\
& =0,8 \times 0,8 \\
& =0,64 \times 100 \% \\
& =64 \%
\end{aligned}
$$

Berdasarkan perhitungan metode Certainty Factor terhadap Pasien-1 didapatkan hasil persentase keyakinannya 64\% dengan diagnosa Dermatitis Iritan.

Proses perhitungan pada Pasien-2, di mana tingkat keyakinannya menggunakan perhitungan Certainty Factor merujuk pada Rumus (2) adalah:

$$
\begin{aligned}
\text { HD1 } & (\text { A02, G16 } \cap \mathrm{G} 07 \cap \mathrm{G} 11) \\
& =\operatorname{Min}[0,8 ; 0,8 ; 0.4] \times 0,6 \\
& =0,4 \times 0,6 \\
& =0,24 \times 100 \% \\
& =24 \%
\end{aligned}
$$

Berdasarkan perhitungan metode Certainty Factor terhadap pasien-2 didapatkan hasil persentase keyakinannya 24\% dengan diagnosa Dermatitis Iritan.

Pada penjabaran proses perhitungan pasien-1 memenuhi kondisi rule 9, yang berarti bahwa seluruh gejala-gejala yang dimasukan oleh user terpenuhi atau sesuai dengan gejala-gejala yang terdapat pada rule 9, yaitu G16, G09, dan G07. Sedangkan pada penjabaran proses perhitungan pasien-2 memenuhi kondisi rule 7 , dengan makna yang sama, bahwa gejala-gejala yang dimasukkan oleh user terpenuhi atau sesuai dengan gejala-gejala yang terdapata pada rule 7, yaitu G16, G07, dan G11. Penerepan rule pada penelitian ini menggunakan gerbang logika $A N D$, yang mana semua kondisi pada suatu rule harus terpenuhi, jika salah satu gejala di suatu rule tidak terpenuhi, maka rule tersebut tidak akan diproses.

\begin{tabular}{|c|c|c|}
\hline No & Pasien & Hasil Uji Data \\
\hline 1 & Pasien-1 & Valid \\
\hline 2 & Pasien-2 & Valid \\
\hline 3 & Pasien-3 & Valid \\
\hline 4 & Pasien-4 & Valid \\
\hline 5 & Pasien-5 & Valid \\
\hline 6 & Pasien-6 & Valid \\
\hline 7 & Pasien-7 & Valid \\
\hline 8 & Pasien-8 & Valid \\
\hline 9 & Pasien-9 & Valid \\
\hline 10 & Pasien-10 & Valid \\
\hline 11 & Pasien-11 & Tidak Valid \\
\hline 12 & Pasien-12 & Valid \\
\hline 13 & Pasien-13 & Valid \\
\hline 14 & Pasien-14 & Valid \\
\hline 15 & Pasien-15 & Valid \\
\hline 16 & Pasien-16 & Valid \\
\hline 17 & Pasien-17 & Valid \\
\hline 18 & Pasien-18 & Valid \\
\hline 19 & Pasien-19 & Valid \\
\hline 20 & Pasien-20 & Valid \\
\hline 21 & Pasien-21 & Valid \\
\hline 22 & Pasien-22 & Valid \\
\hline 23 & Pasien-23 & Valid \\
\hline 24 & Pasien-24 & Valid \\
\hline 25 & Pasien-25 & Valid \\
\hline 26 & Pasien-26 & Valid \\
\hline 27 & Pasien-27 & Valid \\
\hline 28 & Pasien-28 & Tidak Valid \\
\hline 29 & Pasien-29 & Valid \\
\hline 30 & Pasien-30 & Valid \\
\hline 31 & Pasien-31 & Valid \\
\hline 32 & Pasien-32 & Valid \\
\hline 33 & Pasien-33 & Valid \\
\hline 34 & Pasien-34 & Valid \\
\hline 35 & Pasien-35 & Valid \\
\hline 36 & Pasien-36 & Valid \\
\hline 37 & Pasien-37 & Valid \\
\hline 38 & Pasien-38 & Valid \\
\hline 39 & Pasien-39 & Valid \\
\hline 40 & Pasien-40 & Valid \\
\hline 41 & Pasien-41 & Valid \\
\hline 42 & Pasien-42 & Valid \\
\hline 43 & Pasien-43 & Valid \\
\hline 44 & Pasien-44 & Tidak Valid \\
\hline 45 & Pasien-45 & Valid \\
\hline 46 & Pasien-46 & Valid \\
\hline 47 & Pasien-47 & Valid \\
\hline 48 & Pasien-48 & Tidak Valid \\
\hline 49 & Pasien-49 & Valid \\
\hline 50 & Pasien-50 & Valid \\
\hline
\end{tabular}

\subsection{Validasi}

Penelitian ini bertujuan untuk menganalisis alergi kulit pada manusia dengan jumlah data 50 data pasien yang

$$
\text { Tingkat Akurasi }=\frac{\text { Jumlah Data Valid }}{\text { Jumlah Pengujian Data }} \times 100 \%
$$

Hasil dari tingkat akurasi pada 50 data pasien yang telah diuji pada Sistem Pakar yang dibangun dapat dilihat pada Tabel 6

Tabel 6. Tabel Hasil Uji Data 
Dari hasil yang diperolehnya dari 50 data pasien dari diagnosa tersebut. Adapun tampilan halaman pada dilakukan perhitungan untuk mencari persentase hasil diagnosa dapat dilihat pada Gambar 4.

akurasi yang dihasilkan

$$
\text { Tingkat Akurasi }=\frac{46}{50} \times 100 \%=92 \%
$$

Perhitungan yang dilakukan dengan menggunakan rumus (3), maka diperoleh tingkat akurasi Sistem Pakar untuk menganalisis alergi kulit pada manusia dengan metode Certainty Factor adalah sebesar $92 \%$.

\subsection{Hasil}

Dengan melakukan pengolahan 5 data pada

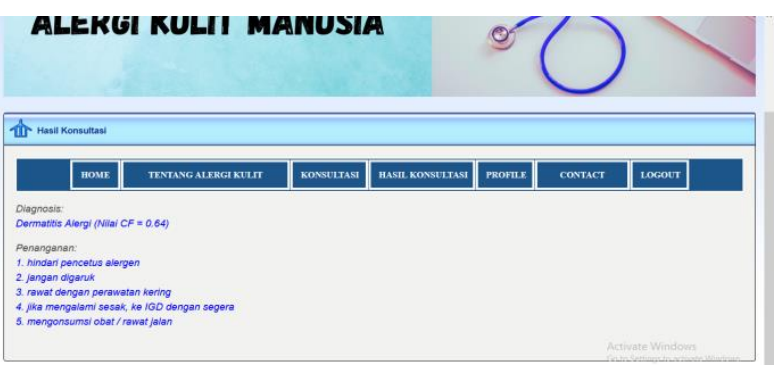

Gambar 4. Tampilan Halaman Hasil Diagnosa pengimplementasian Sistem Pakar menggunakan Dari tampilan hasil diagnosa alergi kulit pasien, metode Certainty Factor, memperoleh hasil diperoleh hasil diagnosa dengan persentase sebesar pengolahan pada Tabel 7:

Tabel 7. Tabel Pengolahan Data Sistem Pakar

\begin{tabular}{lclc}
\hline Pasien & Kode Alergi & Nama Alergi & CF (\%) \\
\hline Pasien-1 & A02 & Dermatitis Iritan & 64 \\
Pasien-2 & A02 & Dermatitis Iritan & 24 \\
Pasien-3 & A01 & Dermatitis Alergi & 48 \\
Pasien-4 & A01 & Dermatitis Alergi & 48 \\
Pasien-5 & A01 & Dermatitis Alergi & 24 \\
\hline
\end{tabular}

Sistem Pakar yang digunakan dapat diakses melalui web browser. Adapun tampilan Sistem Pakar untuk menganalisis alergi kulit pada manusia dapat dilihat pada Gambar 2.

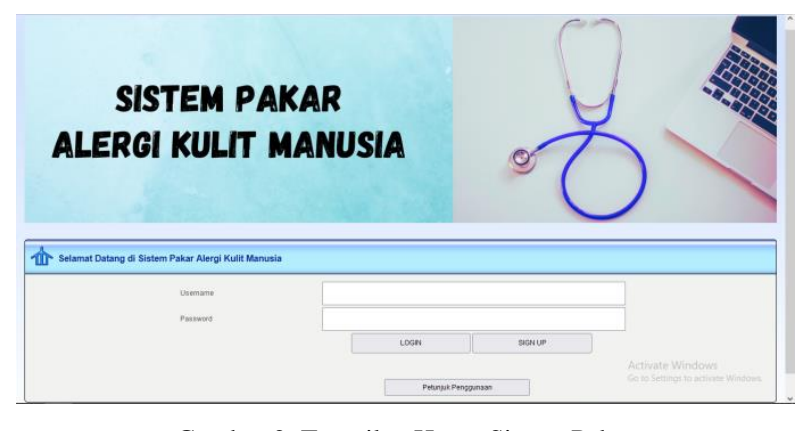

Gambar 2. Tampilan Home Sistem Pakar

Dengan menggunakan Sistem Pakar, user dapat dengan mudah melakukan konsultasi untuk mengetahui diagnosa awal pada alergi kulit yang dialami. Adapun tampilan halaman konsultasi pada Sistem Pakar ini dapat dilihat pada Gambar 3.

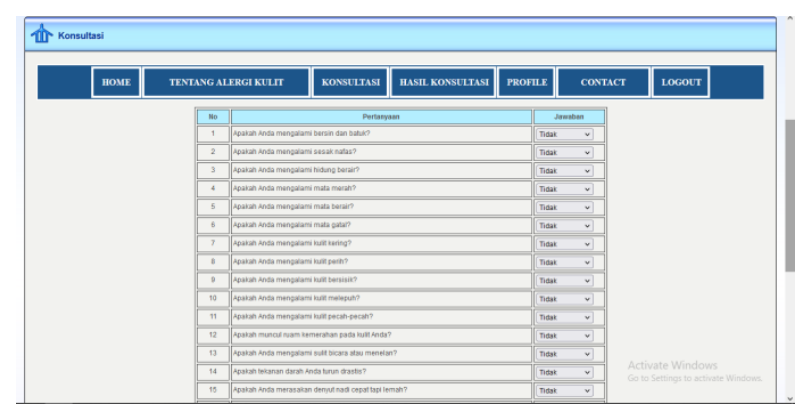

Gambar 3. Tampilan Halaman Konsultasi

Setelah dilakukan konsultasi, user dapat mengetahui diagnosa awal yang diderita beserta solusi penangan
64\% dengan diagnosa alergi Dermatitis Alergi.

\section{Kesimpulan}

Penelitian ini dilakukan untuk menganalisis alergi kulit pada manusia dengan mengimplementasikan Sistem Pakar menggunakan metode Certainty Factor, dengan memproses data sebanyak 50 data pasien, 10 jenis alergi kulit, dan 27 gejala alergi kulit. Hasil implementasi tersebut diperoleh tingkat akurasi sebesar $92 \%$.

\section{Daftar Rujukan}

[1] Kumarahadi, Y. K., Arifin, M. Z., Pambudi, S., Prabowo, T., \& Kusrini, K. (2020). Sistem Pakar Identifikasi Jenis Kulit Wajah dengan Metode Certainty Factor. Jurnal Teknologi Informasi Dan Komunikasi (TIKomSiN), 8(1). doi:10.30646/tikomsin.v8i1.453

[2] Utari, S., Yudatama, U., \& Pujiarto, B. (2020). Media Konsultasi Penyakit Kulit Pada Balita Menggunakan Metode Certainty Factor. Jurnal Komtika (Komputasi Dan Informatika), 3(1), 10-17. doi:10.31603/komtika.v3i1.3463

[3] Putri, N. A. (2018). Sistem Pakar untuk Mengidentifikasi Kepribadian Siswa Menggunakan Metode Certainty Factor dalam Mendukung Pendekatan Guru. INTECOMS: Journal of Information Technology and Computer Science, 1(1), 78-90. doi:10.31539/intecoms.v1i1.164

[4] Fahmi, H. (2019). Sistem Pakar Mendiagnosa Penyakit Mata KatarakDengan Metode Certainty Factor Berbasis Web. Matics, 11(1), 27. doi:10.18860/mat.v11i1.7673

[5] Leidiyana, H., \& Hariyanto, R. D. (2020). Sistem Pakar untuk Mendiagnosa Penyakit Persendian Menggunakan Metode Certainty Factor. Jurnal Komtika (Komputasi Dan Informatika), 4(1), 27-34. doi:10.31603/komtika.v4i1.3701

[6] Hariyanto, R., \& Sa'diyah, K. (2018). Sistem Pakar Diagnosis Penyakit dan Hama Pada Tanaman Tebu Menggunakan Metode Certainty Factor. JOINTECS (Journal of Information Technology and Computer Science), 3(1). doi:10.31328/jointecs.v3i1.500

[7] Santi, I. H., \& Andari, B. (2019). Sistem Pakar Untuk Mengidentifikasi Jenis Kulit Wajah dengan Metode Certainty Factor. INTENSIF: Jurnal Ilmiah Penelitian Dan Penerapan $\begin{array}{llll}\text { Teknologi Sistem Informasi, } & 3(2),\end{array}$ doi:10.29407/intensif.v3i2.12792

[8] Widians, J. A., \& Rizkyani, F. N. (2020). Identifikasi Hama Kelapa Sawit menggunakan Metode Certainty Factor. ILKOM Jurnal Ilmiah, 12(1), 58-63. doi:10.33096/ilkom.v12i1.526.58-63 
[9] Yumiati, S., Saragih, H., Rahman, T. A., \& Triayudi, A. (2021). Expert system for heart disease based on electrocardiogram data using certainty factor with multiple rule. IAES International Journal of Artificial Intelligence (IJAI), 10(1), 43. doi:10.11591/ijai.v10.i1.pp43-50

[10] Wang, Q., Guo, Y., Li, W., He, J., \& Wu, Z. (2019). Predictive modeling of landslide hazards in Wen County, northwestern China based on information value, weights-of-evidence, and certainty factor. Geomatics, Natural Hazards and Risk, 10(1), 820-835. doi:10.1080/19475705.2018.1549111

[11] Akanbi, A. K., \& Masinde, M. (2018). Towards the Development of a Rule-Based Drought Early Warning Expert Systems Using Indigenous Knowledge. 2018 International Conference on Advances in Big Data, Computing and Data Communication Systems (icABCD). doi:10.1109/icabcd.2018.8465465

[12] Konstantinopoulou, G., Kovas, K., Hatzilygeroudis, I., \& Prentzas, J. (2019). An Approach using Certainty Factor Rules for Aphasia Diagnosis. 2019 10th International Conference on Information, Intelligence, Systems and Applications (IISA). doi:10.1109/iisa.2019.8900782
[13]Gunawan, E. P., \& Wardoyo, R. (2018). An Expert System Using Certainty Factor for Determining Insomnia Acupoint. IJCCS (Indonesian Journal of Computing and Cybernetics System), 12(2), 119. doi:10.22146/ijccs.26328

[14]Habibie, D. R., \& Aldo, D. (2019). Sistem Pakar Untuk Identifikasi Jenis Jerawat Dengan Metode Certainity Factor. JOINTECS (Journal of Information Technology and Computer Science), 4(3), 79. doi:10.31328/jointecs.v4i3.1055

[15]Dian, R., Sumijan, S., \& Yunus, Y. (2020). Expert System in Identifying Tooth Damage in Children Using Forward Chaining and Certainty Factor Methods. Jurnal Sistim Informasi Dan Teknologi, 2(3), 1-6. doi:10.37034/jsisfotek.v2i3.36

[16]Zuhriyah, S., \& Wahyuningsih, P. (2019). Pengaplikasian Certainty Factor pada Sistem Pakar untuk Mendiagnosa Penyakit Campak Rubella. ILKOM Jurnal Ilmiah, 11(2), 159166. doi:10.33096/ilkom.v11i2.441.159-166

[17]Putri, L. F. (2020). Perancangan Aplikasi Sistem Pakar Penyakit Roseola Dengan Menggunakan Metode Certainty Factor. Jurnal Sistem Komputer Dan Informatika (JSON), 1(2), 107. doi:10.30865/json.vli2.1956 